\title{
Cultural logic of German foreign direct investment (FDI) in service sector
}

\author{
Bhabani Shankar Nayak ${ }^{1 *}$ and Dominik Scheib²
}

*Correspondence:

bhabani79@gmail.com

${ }^{1}$ Coventry Business School,

Coventry University,

Coventry, UK

Full list of author information

is available at the end of the article

\begin{abstract}
Major studies on FDI looks at location, technology, policy, availability of natural resources, skilled labor, state support, climate, political and economic advantages for investment decisions. There are few studies that look at cultural factors affecting FDI decisions in service. This paper provides qualitative analysis of the impact of national culture on the flow of foreign direct investment in the service sector within the context of Germany. In particular, the paper discusses the cultural logic of German foreign direct investment in the service sector. It argues that inward FDI in the service sector was actually substantially more affected by cultural distance compared to outward FDI. The study finds that it is important to distinguish between inward and outward FDI to assess the cultural logic of German FDI in the service sector.
\end{abstract}

Keywords: Culture, FDI, German, Service sector

\section{Introduction}

One of the most critical and challenging key decisions commonly discussed in the field of international business is the location decision of Foreign Direct Investment (FDI) since its failure causes impactful consequences, financially as well as for the brand image (Galan et al. 2007; Johnson et al. 2006). For this reason, knowledge about why one country invests in another and what influences it is vital for governments and multinational enterprise (MNE) managers alike in order to ensure effective policy-making and to assess potential costs and benefits for firms (Aguiar et al. 2006). Currently, there is a controversial discussion about the decisive factors and polices that influence FDI in the global economy which is also due to the plethora of research about the determinants of FDI which does not find consensus (Du et al. 2012; Mellahi and Guermat 2001; Zait et al. 2014). Consequently, it is impossible to assess all possible determinants of FDI, and hence this dissertation will look at German FDI abroad and how location choices for this type of investment are influenced by cultural differences between home and host country.

There are many forms of distance; i.e., geographical, political or economic, however, as Gomez-Mejia and Palich (1997) pointed out, cultural differences are an inevitable challenge for an internationally expanding firm and crucial to consider. Despite its alleged importance, the plethora of research to determine the reason for FDI abroad all too

(c) The Author(s) 2020. This article is licensed under a Creative Commons Attribution 4.0 International License, which permits use, sharing, adaptation, distribution and reproduction in any medium or format, as long as you give appropriate credit to the original author(s) and the source, provide a link to the Creative Commons licence, and indicate if changes were made. The images or other third party material in this article are included in the article's Creative Commons licence, unless indicated otherwise in a credit line to the material. If material is not included in the article's Creative Commons licence and your intended use is not permitted by statutory regulation or exceeds the permitted use, you will need to obtain permission directly from the copyright holder. To view a copy of this licence, visit http://creativeco mmons.org/licenses/by/4.0/. 
often seems to neglect the relevance of culture and, additionally, underestimates, ignores or not appreciates differences in sectorial characteristics especially in the service sector, but instead uses aggregated data for their analysis which significantly distorts the outcome (Sathe and Handley-Schachler 2006).

The operational aspect of international business demands interaction across borders with people and their firms, which are inherently bound to their culture. The resulting differences in norms, values and beliefs promote misunderstanding and jeopardize business success and eventually can end an FDI endeavor in the red (Constanza 2001). Several scholars and blame the lack of what Johnson et al. (2006) mention in their study to be "cross-cultural competence" as a central factor for the failure of international firms. An understanding and appreciation of cultural differences is paramount to effectively predict responses of and corporate with suppliers, clients and sometimes even competitors which makes comprehending cultural implications of FDI an indispensable necessity especially in the service sector (Constanza 2001; Johnson et al. 2006).

The impact of culture can also be observed by mentioning Kok and Ersoy (2009) who argue that foreign investors are influenced by the profitability of the project, the ease of subsidiary integration and the host country's environment. Especially the latter two factors are believed to be strongly impeded or improved by culture which ultimately affects the first factor (Zait et al. 2014). Consequently, ignoring the cultural foundation of FDI can result in missed opportunities, restricted performance, a complete dissolution of a joint venture or a withdrawal from the market (Stephens and Greer 1995).

Most of the literature generalized on the determinants of FDI. Nowadays, with the dominance of FDI in the service sector for many economies, this can be deemed not to be appropriate anymore. In the past, research has almost exclusively concentrated on FDI in manufacturing or on the aggregation of sectors and strikingly few papers have examined FDI in the service sector. Also for Raff and von der Ruhr (2001) and many others this is surprising given that global FDI stock and flows in the service sector have overtaken the manufacture FDI figure (Kolstad and Villanger 2008), which makes FDI determinants in the service sector crucial for effective policies and educated investment decisions. Countries, for instance, need to re-evaluate if their policies for attracting manufacturing FDI are as effective as for services.

Already Dunning (1998) recognized the gained importance of FDI in the service sector. Clark and Rajaratnam (1999, p. 307) even argue that "the 21st century will be the century of services" amplifying the need for research in this area. With the continuous liberalization of FDI in the service sector, firms have more countries to enter, also countries which are more culturally distant. The "newness" of this type of FDI makes it crucial to investigate.

\section{National culture and FDI}

National culture is a very abstract term and hence extremely difficult to define. One definition comes from Nakata and Sivakumar (2001, p. 257) defining it as "patterns of thinking, feeling and acting that are rooted in common values and conventions of a society". This shared behavior of a nation has led to stereotypes and prejudices in public towards and from nations since national culture means that one specific way of acting or one particular outcome is preferable over another (Newman and Nollen 1996). Such a way or 
outcome may seem odd and strange to outsiders and thus judge them compared to their own ways and preferences. However, scientifically, scholars analyze national culture and those differences in priority objectively and non-judgmentally, so as to evaluate its effect on business encounters and international management. For Hofstede, evaluating cultures is established by assigning cultural scores to each country based on scientific research he conducted at IBM without arguing that, for instance, countries with high scores in one dimension are superior to countries with low scores.

Classifications of culture have been numerous, but the most recognized and commonly accepted constructs by scholars in international business come from Hall's (1976) context paradigm and Hofstede's (1980) cultural dimensions (Laroche et al. 2004).

The establishment of subsidiaries abroad or serving a foreign market otherwise needs to blend in the new, foreign national culture to do business. This mostly inevitably creates tension among parties involved, at both the individual and firm level. Culture has been proved to affect values, perceptions, decision-making or behavior of individuals which ultimately affect investment decisions of firms and purchase decisions of consumers which are two elementary aspects of international business (Hutzschenreuter and Voll 2008). In this dissertation, the four dimensions of national culture from Hofstede (2001) will be used as they have consequences for the comprehension of business behavior around the globe and implications for managing MNEs in different countries that are also believed to have great potential to effect location decisions for FDI in services.

Additionally, for the national culture concept it is important to note that even though Hofstede's dimensions are very helpful to compare one culture with another, those dimensions are only representative at a national level and do not apply to each individual member of this culture (Ghemawat and Reiche 2011). Therefore, results of any study, including this dissertation should be considered as a nation's average rather than applying it to particular people or companies due to spatial homogeneity which was already outlined by Hofstede (1980), emphasizing the difference of culture at national and organizational level. However, the degree of cultural tension can differ among country pairs, and hence the literature review turns to the cultural distance concept.

\section{Role of cultural distance in shaping FDI patterns and policies}

The geographical distribution of FDI is an important issue in international business and distance measures have been the most popular form of analyzing those FDI location decisions (Drogendijk and Martin 2015), although, for instance Kuo and Frang (2009) discuss the diminishing importance of distance due to advanced information and communication technology and their concluding belief that distance is indifferent. However, this dissertation argues that cultural distance cannot be eroded by technology, and hence is still considered an important distance measure.

Cultural distance defined by Luostarinen (1980 as cited in Benito and Gripsrud 1992, p. 467 ) is "the sum of factors creating, on the one hand, a need for knowledge, and on the other hand, barriers to the knowledge flow and hence also for other flows between the home and target country". As the definition outlines, the key aspect is that cultural differences create obstacles which impede flows of knowledge, flows of information and competencies which altogether increase the uncertainty of investments and ultimately the cost of doing business which impairs FDI abroad (Li et al. 2014). Differences due to these hurdles 
include working styles, incentives, consumer behavior or legal system of the country which can promote or harm a country's attractiveness to receive FDI and according to Sakarya, Eckman and Hyllegard (2007), cultural distance is a key factor for a firm's expansion pattern and performance. Moreover, Kogut and Singh (1988) state that this distance can change the nature of FDI. Tahir and Larimo (2004) argue that investors prefer to allocate their assets in culturally close countries rather than in culturally distant. Ultimately, those two cultural concepts are shown to be of high relevance for FDI location decisions, and will form the cultural bases of this dissertation.

\section{German foreign direct investment}

With the increased prominence of free trade agreements, reduced transportation costs and market liberalizations, foreign direct investment has become an important contributor in international business to better exploit company resources and advantages by merging them with foreign country location factors that increases performance. According to the World Bank (The World Bank 2015, para.4), foreign direct investment "[...] is a category of cross-border investment associated with a resident in one economy having control or a significant degree of influence on the management of an enterprise that is resident in another economy", whereas this control or significant degree of influence is generally agreed to be $10 \%$ of ownership acquired (UNCTAD 2009). FDI entails three components which are equity investment, reinvested earning and short- and long-term intercompany loans between parent firm and foreign affiliate (United Nations Department of Economic and Social Affairs 2015). Consequently, FDI abroad consists of assets and liabilities that are exchanged among the investor and the enterprise invested in (The World Bank 2015). Helpman et al. (2004) claim that companies deliberately choose between accommodating foreign customer demands by exports or FDI depending on the costs associated with both modes of entry.

In past decades, there has been a transformation of FDI patterns attributed to the tremendous expansion of FDI in the service sector especially in developed countries (Kolstad and Villanger 2008) and as a result, nowadays most developed economies have a higher share of FDI in the service sector than in the manufacturing sector (Clark and Rajaratnam 1999). For service providers, FDI is one of the most important channels of investment to supply foreign markets accounting for approximately 60\% of global FDI stock (Francois et al. 2009). In Germany, non-financial services even contribute to about $80 \%$ of the total FDI stock making research in this field invaluable for the German economy (Vetter 2014).

Despite its importance for the EU and worldwide economy, studies rarely researched FDI outward determinants for Germany and even less considered disaggregated sector data or culture in their equation. Salavrakos (2009) researched German FDI determinants and came to the conclusion that location-specific factors play a central role for firms' investments abroad. This also includes culture which, however, is not analyzed in detail. According to his research, German FDI goes predominantly to Europe (80\%) and US (11\%). However, it was not found to what extent culture plays a role in this pattern. 


\section{Outward vs. inward German foreign direct investment}

In general, it can be said that culture and economies worldwide become more receptive to FDI. For 2013, UNCTAD (2014) in their World Investment Report counted that 59 countries issued 87 policies affecting FDI from which 61 are of liberalizing nature and 22 are of restricting nature. Important to note is that most of these policies are tailored towards the service sector which is part of the reason for the tremendous rise in the past two decades (UNCTAD 2014). Despite those figures, most restrictions in FDI are still in the service sector which is especially true in developing countries (Duggan et al. 2013) that can be a detriment for German FDI even though the host country's cultural environment may be attractive. Despite its increased prominence in FDI, only little is known about policies in the service sector (Golub 2009). In order to shed light on this, at first German FDI policies and procedures are presented for outward FDI.

\section{German outward FDI}

FDI policies according to iXPOS (2015a) are especially crucial for services as they are more influenced by working processes and legal regulations, national laws and languages that makes it harder for services to be traded and supplied in foreign territory. In order to tackle those barriers of entry, the German government took several policy measures. At first, as of October 2011, Germany has 94 double taxation treaties in place as well as an established network of 139 bilateral investment treaties (BIT) with partner economies (Jost 2011). Those treaties, however, do not discriminate between sectors and are also viable for the manufacturing sector. Those agreements and treaties help to secure German investments abroad and lower the transaction costs. For example, made possible by those BITs, the German government is able to help realizing and financing international projects (BMWi 2015a, b). With those treaties, a safe and stable investment environment is created that especially helps small- and medium-sized companies (SMEs) venture to go abroad which is of crucial importance due to Germany's big middle class, the Mittelstand (BMWi 2015a, b). Due to those BITs, the German government is also able to provide guarantees for FDI that are threatened by, for instance, political risk which amounted to US\$7.2 billion for 86 FDI projects spread over 26 developing countries in 2011 (Jost 2012).

Furthermore, Germany is involved in two trade agreements tailored to the service sector, one of which is the EU directive. As explained, services have to abide to the national law and hence adhere to various regulations in EU countries when they are performed abroad (iXPOS 2015b). The EU directive aims to remove those barriers in the internal EU market to facilitate service operations abroad by obliging to reduce regulation that hamper border crossings and provide information about requirements to set up business in those countries (iXPOS 2015b). Since Europe is the major destination of German FDI, this is likely to have a big impact on FDI abroad in the service sector. A second similar agreement to facilitate access to service markets, however between 23 countries worldwide including Germany making up altogether $70 \%$ of service world trade, is called Trade in Service Agreement (TiSA) which is still being negotiated. With both agreements, Germany intends to increase service investments, especially in its main market Europe. However, TiSA is still under negotiation and no fixed date is set when it shall be concluded (European Commission 2015). 
Besides treaties and agreements, the German government has several institutions whose aims are to support local businesses by providing information, financial support or incentives and thus intend to boost German outward FDI. Incentives exist to gear businesses in order for them to undertake activities and actions that are deemed desirable by the German government (UNCTAD 2014). The purpose of the institution "German Trade and Invest" is to promote Germany as an investment destination and at the same time promoting German foreign trade and investments abroad. This is established, for instance, by providing foreign market information (such as law, regulations, economic activities) made available for 120 countries, by establishing coorporations between German and foreign companies or by supporting SMEs to access markets successfully (Federal Ministry of Economic Affairs and Energy 2015). In addition, there is an institution called DEinternational. Similarly to German Trade and Invest, it is present in 90 countries and provides consultancy and other services to German businesses for a successful market entry or market expansion (DEinternational 2015). It has to be noted that both institutions do not discriminate between sectors. Furthermore, there are also specific programs provided by the Federal Ministry for Economic Cooperation and Development that support German businesses exclusively in developing countries (BMWi 2015a, b).

It is likely that businesses in this sector have specific location advantages as mentioned by Dunning (1980) that would not exist in a foreign country (e.g., technology, infrastructure, suppliers, R\&D). Having a reputation as a country for manufacturing excellence, businesses enjoy the privilege tag "Made in Germany" that can put them in a more advantageous position than its foreign competitors (see literature about Country of Origin effect). This location advantage becomes clear considering that the German economy heavily relies on exports being the "export world champion" of the last decade and just recently was overtaken by China (Federal Ministry of Economics and Technology 2010). This notion is also confirmed by Stopford et al. (1991) stating that strong local firms enjoying location advantages prefer to export their products. Only when it is not feasible anymore to export, e.g., when transports costs explode and the distance to the market matters, FDI is considered (e.g., automobile industry) (Bastasin 2013). The location advantage is also due to the efforts of the German government to safeguard the industrial base and create a productive environment to keep companies in Germany. According to the Federal Ministry of Economics and Technology (2010), this is because of the several location advantages such as a large domestic market, modern infrastructures, skilled workforce and a big share of R\&D-intensive industries. Consequently, the "Standort" Germany, the place of production, became a synonym for a strong industry, so no reason emerged for local firms to go somewhere else (Bastasin 2013). Nevertheless, because Germany is a comparably high-wage country, labor-intensive jobs are shifted to low-cost countries (Bastasin 2013). Especially the Visegrad Group (Poland, Hungary, Czech Republic and Slovakia) has important investment policies in place with Germany that make those countries very attractive for such manufacturing investments abroad (Gross 2013).

In contrast to small manufacturing investments abroad, service investments are comparably very high. In general, services became a crucial necessity for economies worldwide to grow and become efficient that also explain the steep rise during the last two 
decades. Services particularly in business and finance as well as in infrastructure are essential to develop or retain a competitive market. MNEs can help to provide such services and thus indirectly improve a host economy's competitiveness and standard of living (United Nations 2006). The high investment sum particularly of German FDI abroad in the service sector and the resulting large gap to the manufacturing sector can be explained again with advantages and disadvantages of the market rather than policies. Investments in services are not about the production and provision of physical products, but rather about the provision of know-how and information which can be argued to be less location specific to Germany than its manufacturing sector. Even though Germany has highly skilled workers which is a crucial ingredient for a successful service sector (Federal Ministry of Economics and Technology 2010), a location advantage of Germany does not seem to apply in services as they are invested quite a lot abroad (Stopford et al. 1991) and the necessary closeness to the market in services diminishes the German location advantage further. Rather ownership and internalization advantages dominate. Also, with its highly skilled labor, Germany is likely to have a comparative advantage in many countries abroad.

Furthermore, the German domestic service sector is weak and lags behind compared to other developed countries (OECD 2014a). For this reason, a lot of German service businesses expand abroad to find more potential business. Another obvious reason why there is such a big difference between the two sectors in outward FDI is the fact that services cannot be traded as much as products (Kolstad and Villanger 2008). Hence, FDI in the service sector is a "necessary evil" to reach customers in most cases.

Especially developing countries compete among each other for FDI by continuously lowering FDI barriers (Cooray et al. 2014) which will help Germany to exploit them. There is lots of potential in developing countries, especially in the service sector in order to boost their economy, considering that by the end of 2010 only $15 \%$ of German outward FDI stock went to developing countries compared to $85 \%$ in developed countries (Jost 2012). Hence, policies, agreements and further FDI liberalization with those countries can have a big effect and spread the gap between outward FDI in the service and manufacturing sector even wider. Camarero et al. (2019)'s study provides a comprehensive empirical evidence of the determinants of German outward FDI.

Ultimately, German FDI polices for outward investments are to promote and help German businesses to expand and secure their FDI and at the same time reduce restrictions by setting up cooperation, agreements and treaties with partner countries. In the end, however, it is for each host country to decide how much FDI they want to receive. Since host countries are sovereign states, this is beyond the FDI policy power of Germany.

\section{German inward FDI}

Germany is considered to be a very open economy to FDI with no regulations that obstructs everyday business, and by law no distinction is made between foreign and local businesses in the German business environment. The German government reserves the right to impose restrictions on outward and inward FDI if there is concern, for instance, for national security or foreign exchange. These powers, however, are almost never executed (German Trade and Invest 2015a). Golub (2009) also agrees that Germany is among the most open economies. According to the Federal Ministry of Economics and 
Technology (2010) an open market policy is an invaluable task that ensures Germany's future competitiveness and success. Trends such as global value chains, dwindle raw materials as well as the fast demographic change makes an open German market for all sectors indispensable (Federal Ministry of Economics and Technology 2010).

Despite Germany being a manufacturing economy, in 2009, inward FDI stock declined in this sector by $5 \%$, whereas it rose in services (Jost 2011). Since restrictions do not really impede investments in Germany, there must be again market-related forces that explain the different figures of inward FDI in the two sectors. According to Lall and Siddharthan (1982), this has to do with extensive ownership advantages of, in their case, US companies investing abroad so that foreign companies have almost no chance of competing successfully in the US. The manufacturing sector are even half in contrast to outward FDI figures, and hence German firms in the manufacturing sector tend to have strong advantages over their foreign counterparts that make it challenging for them to compete in the German market, supporting the arguments of Lall and Siddhartan's (1982). This strength is shown as Germany countered the recent economic crises relatively well which according to Schwab (2014) is due to its competitive strengths such as Germany's highly sophisticated businesses. Moreover, due to high labor costs in Germany, when investing in less innovative and less competitive German industries, labor costs are likely to be higher than elsewhere, reducing the profitability of foreign investment.

On the other hand, foreign firms have sometimes strong intangible assets that provide them with the strength to make investments (Li and Guisinger 1991). Also, the weakness of the domestic German service sector can help foreign investors to succeed. Advantages of foreign firms in intangible assets, higher productivity and other know-how is likely the case in the service sector which is less than outward FDI abroad, but still by far dominating German inward FDI. Those advantages make it easier for foreign firms to compete in Germany and services seem to be much needed by the German economy. Services are needed in order to enable German businesses to produce high-quality products efficiently and to the highest standards in order to retain its role in the global economy (United Nations 2006). According to OECD (2014a), services are essential to upgrade and differentiate products which emphasizes the important role of services in the German economy. In other words, services are crucial for an economy to function and there is a synergy effect of manufacturing and service sector (Czarnitzki and Spielkamp 2000; Duggan et al. 2013). So, there is high demand for service investments in Germany to keep the manufacturing sector, the German growth engine, at its best. Another explanation for the high FDI inward figures in services is Germany's sophisticated infrastructure. Walsh and $\mathrm{Yu}$ (2010) found in their study that the better the infrastructure of a country, the more FDI in services this country receives. Such a good infrastructure network is important for Germany's economy, as an innovative market requires especially knowledge-intensive services and an efficient service industry (Federal Ministry of Economics and Technology 2010). Knowledge-intensive services require highly skilled workers which, as of now, are still present in Germany (Schwab 2014). However, with the fast occurring demographic shift in the German population, the German economy already feels the impact of missing talent (Federal Ministry of Economics and Technology 2010) that makes an open service sector even more important. 
However, despite the general claim from researchers and statistics of an open German economy, there are in fact still restrictions in the German service sector, for instance, in order to protect consumers (OECD 2014b). Those restrictions impede inward FDI in services and are blamed for the lack of competition in the German domestic service sector, for tight regulations in the professional services sector and thus for a lack of productivity that hinders the German service sector to unfold to its fullest potential (OECD 2014a, b), which is even appreciated by the Federal Ministry of Economics and Technology (2010). For instance, compared to other OECD countries, professional services such as architects, engineers and lawyers are more regulated. There are regulations on prices and fees, as well as restrictions in the advertising sector (OECD 2014a). The most regulated services by the German government are air transport, legal and accounting services (OECD 2014c). For instance, only in air transportation limitations for foreign equity exist (OECD 2014c). Further hurdles for foreign direct investors in the service sectors are the unclear criteria for recognition of foreign qualifications or the restricted temporary movement of suppliers (OECD 2014a). According to OECD (2014b), improvements can be made in terms of price regulation without affecting customer protection. Further OECD (2014b) suggests that deregulation in professional services will have a big impact in the service sector, which also will have a spillover effect on FDI as professional services account for 10\% of German GDP. Furthermore, in 2008, the German government issued a new law to screen certain foreign investments, especially those from foreign state-owned businesses (Marchick and Slaughter 2008). This is to control the influence on public policies and national security, and is only executed when a foreign stake exceeds 25\% (Marchick and Slaughter 2008). So, while very liberal and open, Germany still tries to protect its economy where deemed necessary. Whereas soft German regulations are necessary to protect national interests, too strict regulations will limit employment possibilities, competition and productivity and in turn protects an inefficient system which can be argued to be unsustainable (OECD, 2014a). Consequently, according to OECD (2014a), removing barriers in the German service sector will not only boost domestic demand and productivity, but will also help the German manufacturing sector to flourish as a hub of global value chains. Also, the OECD (2014a) suggests abandoning or further reducing those restrictions. The effects of no restrictions can be seen in the manufacturing sector which is completely open to international markets and hence competition. As a result, the sector's productivity and innovativeness is admired by many nations (OECD 2014b). Despite those restrictions in the service sector, there are high amounts of FDI to take their share and exploit their advantages. Therefore, Germany is still believed to have an overall very open economy, with a strong cultural orientation.

But Deutsche Bank Research (2008) raises concerns about lowering restrictions and liberalizing FDI policies only to have a modern economic structure, hence an economy with a large tertiary sector. The service sector share in Germany's GDP is relatively low compared to the UK, United States or France (Deutsche Bank Research 2008), arguing that the economy is not on track with Germany's development. However, Deutsche Bank Research (2008) argues that the ideal size, and consequently, the share of the service sector in a country's GDP cannot be quantified. Often, an "old economy" with a smaller service sector such as in Germany can prove to be very competitive and modern (Deutsche 
Bank Research 2008). For this reason, new FDI policies in services have to be carefully analyzed and assessed to not jeopardize Germany's economic strength.

Besides those restrictions, the German government also provides incentives for investments in Germany, again which apply to both German and foreign businesses alike (Germany Trade and Invest 2015b). Those incentives aim to steer investments in disadvantaged regions or specific industries that need support (UNCTAD 2014). There are two basic incentive packages. One is "the investment incentive package" which aims at reimbursing costs for investments that include cash incentives, public loans or public guarantees (Germany Trade and Invest 2015b). According to a survey mentioned in UNCTAD (2014), those fiscal incentives have the greatest effects for attracting foreign investments. The second package is "the operational incentive package" coping with subsidizing costs related, for instance, to labor, tax and R\&D programs once the investment has been made (Germany Trade and Invest 2015b; Invest in EU 2013). As an example, for R\&D companies this is established by providing extra low interest rate loans (Invest in EU 2013). Furthermore, the receivers of such packages have been clearly defined depending on, firm size or industry (Germany Trade and Invest 2015b). In general, foreign investors are welcome to invest in all sectors and are entitled to $100 \%$ ownership of their investment and are also granted to invest in sectors such as mail or telecommunications (Invest in EU 2013).

\section{Conclusion}

Since the big difference in FDI between services and manufacturing cannot be explained by FDI policies alone, as for example Germany is very open and seldom discriminates between sectors, market forces such as the OLI advantages as well as competitive advantages and FDI policies of the host countries in the case of outward FDI are more appropriate for assessing the wide difference between those two sectors. When comparing those two flows of investment, German inward and outward FDI, it becomes clear that ownership, location and internalization advantages are different in importance depending on the sector as well as the flow of investment. Since the OLI advantages, are also influenced by culture, this influence thus is argued to also depend on the flow of investment making a distinction of inward and outward FDI necessary. In general, ownership advantages seem to be less strong for inward FDI in the service sector given the big amount of inward FDI, whereas location advantage seems to be less important for outward FDI in services given the big investment abroad compared to the manufacturing sector whose production base in Germany can be considered as their competitive strength. The current account surpluses of Germany reflect this comparative advantage (Federal Ministry of Economics and Technology 2010). In addition, policies and promotions do vary among inward and outward FDI. Whereas Germany is a very open economy for inward FDI with few restrictions in the service sector and an almost completely open manufacturing sector, coping with outward FDI is more challenging for the German government as FDI policies by host governments cannot be influenced but rather reduced by promoting bilateral agreements, treaties and trade agreements. Consequently, the German government can only support German businesses to cope with these FDI policies of the host government in the best and most effective way. In 
general, as of now, developing countries even when continuously liberalizing the service sector are more restricted than developed nations such as Germany (Golub 2009), which means German outward FDI in the service sector tends to be more restricted than German inward FDI in services and hence can bias the results when analyzed in bilateral flows.

Ultimately, as different parties and policies promote or hamper FDI depending on the direction they flow, it is important to only analyze one direction as these interferences may be less or more based on cultural differences. Hence, various determinants of FDI and policies are more or less significant in explaining location choices depending on the direction of the investment. Those policies and arrangements can further make cultural influences be more or less influential for FDI, since the influence of those policies depends on the direction of investment flows. In terms of culture, also Lee et al. (2007) proposed that outward FDI is likely to be more prone to culture as inward FDI in terms of cross-border cooperation. While with inward FDI, the company must solely adapt to a foreign partner, outward FDI must adapt to both a foreign partner and a foreign environment (Lee et al. 2007). However, they found that inward FDI was actually substantially more affected by cultural distance compared to outward FDI. The study reconfirms that it is important to distinguish between inward and outward FDI, thus to assess only one direction opposed to assessing bilateral flows all at once or project result from one direction on the other.

\section{Acknowledgements}

This paper represents the personal opinions of individual staff members and is not meant to represent the position or opinions of our employers. The authors would like to express their sincere gratitude to the anonymous reviewers for their useful comments. Any errors or omissions are the fault of the authors.

\section{Authors' contributions}

The two authors contributed to the drafting of all sections of the paper. Both authors read and approved the final manuscript.

Funding

This work has not been supported by any funding agencies.

Availability of data and materials

We used publicly available data and materials.

Competing interests

We hereby confirm that there are no potential conflicts of interest relating to this paper apart from the disclaimer included in "Acknowledgements".

Author details

${ }^{1}$ Coventry Business School, Coventry University, Coventry, UK. ${ }^{2}$ Lidl Stiftung \& Co. KG, Stuttgart und Umgebung, Deutschland.

Received: 12 October 2019 Revised: 29 February 2020 Accepted: 2 April 2020

Published online: 07 April 2020

\section{References}

Aguiar S, Aguiar-Conraria L, Gulamhussen MA, Magalhaes PC (2006) Foreign direct investment and home country political risk: the case of Brazil. http://www3.eeg.uminho.pt/economia/nipe/docs/2006/NIPE_WP_7_2006.pdf. Accessed 9 Oct 2019

Bastasin C (2013) Germany: a global miracle and a European challenge. http://www.brookings.edu/ /media/research/ files/papers/2013/05/germany-economy-european-challenge-bastain/05_germany_economy_euro_challenge_ bastasin.pdf. Accessed 9 Oct 2019

Benito GRG, Gripsrud G (1992) The expansion of foreign direct investments: discrete rational location choices or a cultural learning process? J Int Bus Stud 23(3):461-476. https://doi.org/10.1038/nrc821

BMWi (2015a) Increasing Investment in Germany, Report prepared by The Expert Commission on behalf of the Federal Minister for economic affairs and energy, Gigmar Gabriel, Germany. https:/www.bmwi.de/Redaktion/EN/Publikatio nen/staerkung-von-investitionen-in-deutschland-en.pdf?_blob=publicationFile\&v=1. Accessed 9 Oct 2019 
Bundesministerium für Wirtschaft und Energie (BMWi) (2015b) Finanzierung und Absicherung von Auslandsgeschäften. http://www.bmwi.de/DE/Themen/Aussenwirtschaft/Aussenwirtschaftsfoerderung/finanzierung-und-absicherun g-von-auslandsgeschaeften.html. Accessed 9 Oct 2019

Camarero M, Montolio L, Tamarit C (2019) Alternative estimators for the FDI gravity model: an application to german outward FDI. Working Papers 1907, Department of Applied Economics II, Universidad de Valencia

Clark T, Rajaratnam D (1999) International services: perspectives at century's end. J Serv Mark 13(4/5):298-310

Constanza B (2001) The effect of cultural differences on service encounter satisfaction. In: Proceedings 2001 AMA winter educator's conference, pp 46-52. http://eprints.qut.edu.au/15483/1/15483.pdf. Accessed 9 Oct 2019

Cooray A, Tamazian A, Vadlamannati KC (2014) What drives FDI policy liberalization? An empirical investigation. Reg Sci Urban Econ 49:179-189

Czarnitzki D, Spielkamp A (2000). Business services in Germany: bridges for innovation. Retrieved 2 March 2015 from http://econstor.eu/bitstream/10419/24400/1/dp0052.pdf

DEinternational (2015) Für Ihren Geschäftserfolg im Ausland - DEinternational. Retrieved 3 March 2015 from http://www. deinternational.de/. Accessed 9 Oct 2019

Deutsche Bank Research (2008) Germany the service society—but don't forget the industrial sector! http://www.dbres earch.ru/PROD/DBR_INTERNET_EN-PROD/PROD0000000000221912.pdf;jsessionid=1B447AD0E5170525DF5442EB7 339A563.srv-net-dbr-com. Accessed 9 Oct 2019

Drogendijk R, Martin OM (2015) Relevant dimensions and contextual weights of distance in international business decisions: evidence from Spanish and Chinese outward FDI. Int Bus Rev 24(1):133-147

Du J, Lu Y, Tao Z (2012) Institutions and FDI location choice: the role of cultural distances. J Asian Econ 23(3):210-223

Duggan V, Rahardja S, Varela G (2013) Can open service sector FDI policy enhance manufacturing productivity? Evidence from Indonesia. Retrieved 4 March 2015 from http://siteresources.worldbank.org/EXTPREMNET/Resources/EP106 .pdf. Accessed 9 Oct 2019

Dunning JH (1980) Toward an eclectic theory of international production: some empirical tests. J Int Bus Stud 11(1):9-31

Dunning JH (1998) Globalization and the new geography of foreign direct investment. Oxford Dev Stud 26(1):47-69

European Commission (2015) Trade in services agreement (TiSA). http://ec.europa.eu/trade/policy/in-focus/tisa/. Accessed 9 Oct 2019

Federal Ministry of Economic Affairs and Energy (2015) Institutions that promote foreign trade and investment. http:// www.bmwi.de/EN/Topics/Foreign-trade/institutions-that-promote-foreign-trade-and-investment.html. Accessed 9 Oct 2019

Federal Ministry of Economics and Technology (2010) In focus: Germany as a competitive industrial nation. http://www. bmwi.de/English/Redaktion/Pdf/germany-industry-nation, property=pdf,bereich=bmwi,sprache=en,rwb=true. pdf. Accessed 9 Oct 2019

Francois J, Pindyuk O, Woerz J (2009) Trends in international trade and FDI in services. https://ideas.repec.org/p/lnz/ wpaper/20090802.html. Accessed 9 Oct 2019

Galan Jl, González-Benito J, Zunga-Vincente JA (2007) Factors determining the location decisions of Spanish MNEs: an analysis based on the investment development path. J Int Bus Stud 38(6):975-997

Germany Trade and Invest (2015a) Foreign businesses in Germany. http://www.gtai.de/GTAI/Navigation/EN/Invest/Inves tment-guide/The-legal-framework/foreign-businesses-in-germany.html. Accessed 9 Oct 2019

Germany Trade and Invest (2015b) Incentives at a glance. http://www.gtai.de/GTAI/Navigation/EN/Invest/Investment -guide/Incentive-programs/incentives-at-a-glance.html. Accessed 9 Oct 2019

Ghemawat P, Reiche S (2011) National cultural differences and multinational business. http://www.aacsb.edu/ /media/ AACSB/Publications/CDs\%20and\%20DVDs/GLOBE/readings/national-cultural-differences-and-multinational-busin ess.ashx. Accessed 9 Oct 2019

Golub SS (2009) Openness to foreign direct investment in services: an international comparative analysis. World Econ 32(8):1245-1268

Gomez-Mejia L, Palich L (1997) Cultural diversity and the performance of multinational firms. J Int Bus Stud 28(2):309-335

Gross SG (2013) The German economy today: exports, foreign investment, and east-central Europe in NYU CEMS Max Weber Chair conference 2013 working paper. http://cems.as.nyu.edu/docs/CP/4751/MWFinal.ac.pdf. Accessed 9 Oct 2019

Hall ET (1976) Beyond culture. Anchor Press, Garden City

Helpman E, Melitz M, Yeaple S (2004) Export versus FDI with heterogeneous firms. Am Econ Rev 94(1):300-316

Hofstede G (1980) Culture's consequences: international differences in work-related values. Sage Publications, Beverly Hills

Hofstede G (2001) Culture's consequences, 2nd edn. Sage Publications Inc. Thousand Oaks

Hutzschenreuter T, Voll JC (2008) Performance effects of "added cultural distance" in the path of international expansion: the case of German multinational enterprises. J Int Bus Stud 39(1):53-70

Invest in EU (2013) Germany — a major destination for foreign investment. http://www.investineu.com/content/germa ny-\%E2\%80\%93-major-destination-foreign-investment. Accessed 9 Oct 2019

iXPOS (2015a) Service industry. http://www.ixpos.de/IXPOS/Navigation/EN/Your-business-in-germany/Eu-service-marke t/service-industry.html. Accessed 9 Oct 2019

iXPOS (2015b) EU services directive. http://www.ixpos.de/IXPOS/Navigation/EN/Your-business-in-germany/Eu-servicemarket/eu-services-directive.html. Accessed 9 Oct 2019

Johnson JP, Lenartowicz T, Apud S (2006) Cross-cultural competence in international business: toward a definition and a model. J Int Bus Stud 37(4):525-543

Jost T (2011) Inward FDI in Germany and its policy context: update 2011. http://academiccommons.columbia.edu/item/ ac:142670. Accessed 9 Oct 2019

Jost T (2012) Outward FDI from Germany and its policy context, 2012. http://academiccommons.columbia.edu/catalog/ ac\%3A154500. Accessed 9 Oct 2019

Kogut B, Singh H (1988) The effect of national culture on the choice of entry mode. J Int Bus Stud 19(3):411-432

Kok R, Ersoy BA (2009) Analyses of FDI determinants in developing countries. Int J Soc Econ 36(1/2):105-123 
Kolstad I, Villanger E (2008) Determinants of foreign direct investment in services. Eur J Polit Econ 24(2):518-533

Kuo CL, Frang WC (2009) Psychic distance and FDI location choice: empirical examination of taiwanese firms in China. Asia Pac Manag Rev 14(1):85-106

Lall S, Siddharthan SN (1982) Monopolistic advantages of multinationals: lessons from foreign investment in the US. Econ J 92(367):668-683

Laroche M, Ueltschy LC, Abe S, Cleveland M, Yannopoulos PP (2004) Service quality perceptions and customer satisfaction: evaluating the role of culture. J Int Mark 12(3):58-85

Lee J, Garbarino E, Lerman D (2007) How cultural differences in uncertainty avoidance affect product perceptions. Int Mark Rev 24(3):330-349

Li J, Guisinger S (1991) Comparative business failure of foreign-controlled firms in the united states. J Int Bus Stud 22(2):209-224

Li C, Brodbeck FC, Shenkar O, Fisch JH (2014) Cultural attractiveness: a neglected variable in foreign direct investment. http://www.psy.Imu.de/wirtschaftspsychologie/forschung/working_papers/wop2014_2.pdf. Accessed 9 Oct 2019

Luostarinen R (1980) Internationalization of the firm. Helsinki School of Economics, Helsinki

Marchick DM, Slaughter MJ (2008) Global FDI policy: correcting a protectionist drift. CSR no. 34 (June). Council on Foreign Relations

Mellahi K, Guermat C (2001) What motivates foreign direct investment? The case of Oman. https://businessschool.exete r.ac.uk/documents/papers/management/2002/0201.pdf. Accessed 9 Oct 2019

Nakata C, Sivakumar K (2001) Instituting the marketing concept in a multinational setting: the role of national culture. J Acad Mark Sci 29(3):255-275

Newman KL, Nollen SD (1996) Culture and congruence: the fit between management practices and national culture. J Int Bus Stud 27(4):753-779

OECD (2014a) Germany — keeping the edge: competitiveness for inclusive growth. http://www.oecd.org/germany/Bette r-policies-germany.pdf. Accessed 9 Oct 2019

OECD (2014b) OECD economic surveys Germany. http://www.oecd.org/eco/Germany-Overview-2014.pdf. Accessed 9 Oct 2019

OECD (2014c) OECD services trade restrictiveness index (STRI): Germany. http://www.oecd.org/tad/services-trade/ STRI_DEU.pdf. Accessed 9 Oct 2019

Raff H, von der Ruhr M (2001) Foreign direct investment in producer services: theory and empirical evidence, No 598, CESifo Working Paper Series, CESifo Group Munich

Sakarya S, Eckman M, Hyllegard KH (2007) Market selection for international expansion. Int Mark Rev 24(2):208-238

Salavrakos ID (2009) Determinants of German foreign direct investment: a case of failure? Eur Res Stud 12(2):3-26

Sathe S, Handley-Schachler M (2006) Social and cultural factors in FDI flows: evidence from the Indian states. World Rev Entrep Manag Sustainable Dev 2(4):323-334

Schwab K (2014) The global competitiveness report 2014-2015. http://www3.weforum.org/docs/WEF_GlobalCompetiti venessReport_2014-15.pdf. Accessed 9 Oct 2019

Stephens GK, Greer CR (1995) Doing business in Mexico: understanding cultural differences. Organ Dyn 24(1):39-55

Stopford JM, Strange S, Henley JS (1991) Rival states, rival firms competition for world market shares. Cambridge University Press, Cambridge

Tahir R, Larimo J (2004) Understanding the location strategies of the European firms in Asian countries. J Am Acad Bus 5(1/2):102-109

The World Bank (2015). What is the difference between Foreign Direct Investment (FDI) net inflows and net outflows? https://datahelpdesk.worldbank.org/knowledgebase/articles/114954-what-is-the-difference-between-foreign-direc t-inve. Accessed 9 Oct 2019

United Nations (2006) Measuring restrictions on FDI in services in developing countries and transition economies. http:// unctad.org/en/docs/iteiia20061_en.pdf. Accessed 9 Oct 2019

United Nations Conference on Trade and Development (UNCTAD) (2009) UNCTAD training manual on statistics for FDI and the operations of TNCs. http://unctad.org/en/Docs/diaeia20091_en.pdf. Accessed 9 Oct 2019

United Nations Conference on Trade and Development (UNCTAD) (2014) World investment report 2014_investing in the SDG's: an action plan. http://unctad.org/en/publicationslibrary/wir2014_en.pdf. Accessed 9 Oct 2019

United Nations Department of Economic and Social Affairs (2015) Foreign direct investment (FDI) net inflows and net outflows as share of GDP. http://www.un.org/esa/sustdev/natlinfo/indicators/methodology_sheets/global_econ_ partnership/fdi.pdf. Accessed 9 Oct 2019

Vetter S (2014). Recent trends in FDl activity in Europe. https://www.dbresearch.com/PROD/DBR_INTERNET_EN-PROD/ PROD0000000000340841/Recent+trends+in+FDI+activity+in+Europe\%3A+Regaining.pdf. Accessed 9 Oct 2019

Walsh JP, Yu J (2010). Determinants of foreign direct investment: a sectoral and institutional approach. IMF working paper. https://www.imf.org/external/pubs/ft/wp/2010/wp10187.pdf. Accessed 9 Oct 2019

Zait W, Warter I, Warter L (2014) Cross-cultural incentives for the FDI. Cross-Cult Manag J 16(1):209-222

\section{Publisher's Note}

Springer Nature remains neutral with regard to jurisdictional claims in published maps and institutional affiliations. 